\title{
Adherence Improvement Of Five Moments Hand Hygiene With Increasing Motivation Of Nurses
}

\author{
Menik Kustriyani 1, Ivana Probo Kaeksi ${ }^{2}$, Tamrin³ \\ 1,2,3 Sekolah Tinggi Ilmu Kesehatan Widya Husada Semarang
}

\section{Article Info}

Article History:

Accepted Jan 15th 2018

Key words:

Five moment hand hygiene

Motivation

Obidience

Abstract
Joint Commission International ( JCI ) required the achievement of $100 \%$
five moment hand hygiene for the nurses who have provided care to
patients. The adherence of five moments hand hygiene has been done to
reduce the incidence of nosocomial infections. The adherence of five
moments hand hygiene has been determined by inside and outside factors,
and one of the inside factors is the motivation. The research is a
quantitative research with cross sectional approach. The number of sample
is 153 nurses with the proportionate random sampling technique at the
Public Hospital of Loekmono Hadi Kudus. The research instruments used
the questionaire and observation sheet. The research showed the result of
Rank Spearman test p value $=0,000$ with $r$ value $=0.296$, positive
correlation means that the higher the nurse motivation, the higher the
nurse aderence of five moment hand hygiene.

\section{PENDAHULUAN}

Tindakan pelayanan kesehatan dapat berisiko kepada terjadinya infeksi nosokomial, misalnya suntikan/ pengambilan darah, tindakan bedah dan kedokteran gigi, persalinan, pembersihan cairan tubuh, dan lain-lain. Salah satu upaya pengendalian infeksi di rumah sakit dilakukan universal precaution. Universal Precaution merupakan upaya yang dilakukan dalam rangka perlindungan, pencegahan dan meminimalkan infeksi silang (cross infections) petugas akibat adanya kontak langsung dengan pasien atau cairan tubuh pasien yang terinfeksi penyakit menular (seperti HIV/ AIDS dan hepatitis). Diharapkan setiap petugas pelayanan kesehatan mampu menerapkan prinsip universal precaution. Penerapan kewaspadaan universal ini bertujuan tidak hanya melindungi petugas dari resiko terkena infeksi namun juga melindungi pasien yang mempunyai kecenderungan rentan terhadap segala macam infeksi yang mungkin terbawa oleh petugas (Depkes, 2011). Salah satu upaya dalam mencegah infeksi nosokomial adalah dengan membudayakan kepatuhan mencuci tangan di kalangan petugas kesehatan (Lairing, 2014).

Mencuci tangan merupakan komitmen rumah sakit dalam prosedur pengontrolan infeksi dan merupakan metode terbaik dalam mencegah transmisi mikroorganisme (James, 2008). Pencegahan dalam terjadinya infeksi nosokomial dapat 
dilakukan dengan cara mencuci tangan sebelum kontak dengan pasien, sebelum melakukan tindakan septik/ antiseptik, sesudah kontak dengan pasien, sesudah terpapar dengan cairan tubuh pasien dan sesudah kontak dengan lingkungan pasien. Kelima kondisi tersebut dikenal dengan istilah five moment hand hygiene (WHO, 2010).

Menurut data Riset Kesehatan Dasar (RISKESDAS) tahun 2007, prevalensi nasional berperilaku benar dalam cuci tangan di rumah sakit adalah 23, 2\%. Hasil penelitian yang dilakukan oleh Chang, NaiChung, dkk (2013) tentang pelaksanaan five moment hand hygiene pada seluruh tenaga kesehatan di 3 rumah sakit di Amerika, didapatkan hasil tenaga kesehatan yang melaksanakan five moment hand hygiene di kamar bedah sebanyak 40, 8\% dan tenaga kesehatan yang melaksanakan five moment hand hygiene di ruang Intensif Care Unit (ICU) sebanyak 69, 2\%, sedangkan pada 3 rumah sakit yang berbeda di Skotlandia, dari total 233 perawat yang melaksanakan five moment hand hygiene sebanyak 214 (92\%) dan yang tidak melaksanakan five moment hand hygiene sebanyak 19 (8\%) (Price, Lesley, dkk, 2013).

Presentase kepatuhan perawat terhadap five moment hand hygiene di RSUP Dr. Wahidin Sudirohusodo Makassar khususnya ruang Intensif Care Unit (ICU) pada bulan April 2013 hanya mencapai 50\% sedangkan pada bulan Mei 2013 turun menjadi $40 \%$. Di ruang Neonatal Intensif Care Unit (NICU) pada bulan April 2013, tingkat kepatuhan mencuci tangan 60\% sedangkan pada bulan Mei 2013 menurun menjadi $45 \%$. Data ini menunjukkan bahwa tingkat kepatuhan perawat terhadap five moment hand hygiene di ruang ICU dan NICU masih belum konsisten (Lairing, 2014).

Hasil penelitian Rodyah, Silvi Anita Uslatu (2015), didapatkan kepatuhan perawat dalam melaksanakan five moment hand hygiene di RSU Kaliwates PT Rolas
Nusantara Medika Jember yaitu sebesar 21 $(65,6 \%)$ perawat dengan kategori tidak patuh dan 11 (34, 4\%) perawat dengan kategori patuh. Hasil penelitian Sukron (2013), tentang tingkat kepatuhan perawat dalam pelaksanaan five moment hand hygiene di IRNA C RSUP Fatmawati dapat diketahui bahwa responden yang memiliki tingkat kepatuhan kurang sebanyak 67 orang $(69,1 \%)$, kepatuhan sedang sebanyak 18 orang $(18,6 \%)$ dan kepatuhan baik sebanyak 12 orang (12,4\%). Jadi dapat disimpulkan bahwa sebagian besar responden adalah yang mempunyai kepatuhan kurang sebanyak 67 orang (69, $1 \%)$.

Kepatuhan cuci tangan perawat sangat perlu diperhatikan agar tetap dilaksanakan sesuai dengan standar operasional prosedur yang ada yaitu dengan cara enam langkah dan lima momen yang tepat. Pelaksanaan cuci tangan yang baik dan benar dilakukan karena adanya faktor dari dalam dan luar dari diri perawat itu sendiri, salah satunya yaitu motivasi. Motivasi kepatuhan perawat dalam five moment hand hygiene berarti dorongan karena faktor-faktor tertentu yang menyebabkan individu akan melakukan tugas-tugas sesuai dengan standar prosedur yang telah ditetapkan (Mathuridy, 2015).

Motivasi untuk patuh dalam melaksanakan five moment hand hygiene ketika berada dalam ruangan sebelum atau sesudah melakukan aktivitas terhadap pasien masih kurang terutama untuk tindakan yang berisiko rendah, meskipun sarana untuk palaksanaan five moment hand hygiene sudah tersedia di ruangan yang sama dan mudah diakses. Motivasi yang dimiliki seharusnya dapat meningkatkan kepatuhan perawat dalam melaksanakan enam langkah lima momen cuci tangan yang baik dan benar (Mathuridy, 2015).

Penelitian yang dilakukan oleh Mathuridy (2015), di Rumah Sakit Umum Daerah (RSUD) Ulin Banjarmasin ruang ICU, didapatkan hasil dari 30 orang perawat 
dengan motivasi sedang kepatuhan sedang yaitu 6 orang $(54,5 \%)$, motivasi sedang kepatuhan tinggi yaitu 5 orang (45, 5\%), motivasi tinggi kepatuhan sedang yaitu 2 orang $(6,7 \%)$, motivasi tinggi kepatuhan tinggi yaitu 17 orang $(89,5 \%)$.

Hasil penelitian Apriliantari (2015), sebagian besar perawat di IRNA C RSUP Sanglah Denpasar memiliki motivasi cuci tangan enam langkah lima momen dengan kategori tinggi $(89,8 \%)$. Hasil penelitian lain didapatkan motivasi perawat pelaksana di RSUD Batang dapat dilihat bahwa dari 34 responden lebih dari separuh yaitu 20 responden $(58,8 \%)$ mempunyai motivasi rendah dan kurang dari separuh yaitu 14 responden $(41,2 \%)$ mempunyai motivasi tinggi dalam melaksanakan perawatan luka post operasi (Devi dan Wijayanti, 2013).

\section{METODE}

Jenis penelitian yang digunakan adalah penelitian kuantitatif yang merupakan penelitian non experimental dengan menggunakan desain cross sectional. Penelitian ini dilakukan pada bulan JuliAgustus 2017. Sampel dalam

penelitian ini adalah perawat yang berada di ruang rawat inap RSUD dr. Loekmono Hadi Kudus sebanyak 153 perawat Tekhnik pengambilan sampel dalam penelitian ini adalah menggunakan tekhnik proportionate random sampling. Variabel independennya yaitu motivasi perawat dan variabel dependennya yaitu kepatuhan perawat dalam melaksanakan five moment hand hygiene. Instrumen pada penelitian ini menggunakan kuesioner dan lembar observasi dan dianalisis menggunakan uji Rank Spearman.

\section{HASIL}

\section{Karakteristik Responden Berdasarkan Umur}

Tabel 1

Distribusi Frekuensi Responden Berdasarkan Umur di Ruang Rawat Inap RSUD dr. Loekmono Hadi Kudus Juli - Agustus 2017 n=153

\begin{tabular}{ccc}
\hline Usia & Frekuensi & Persentase (\%) \\
\hline $17-25$ & 61 & 39,9 \\
$26-35$ & 78 & 51,0 \\
$36-45$ & 14 & 9,2 \\
\hline Total & $\mathbf{1 5 3}$ & $\mathbf{1 0 0}$ \\
\hline
\end{tabular}

Hasil penelitian ini sesuai dengan penelitian Roatib (2007), pada variabel umur diperoleh nilai signifikansi 0,021 hal ini menunjukkan bahwa ada hubungan yang bermakna antara umur perawat dengan motivasi perawat dalam menerapkan komunikasi terapeutik. Secara fisiologi pertumbuhan dan perkembangan seseorang dapat digambarkan dengan pertambahan umur, peningkatan umur diharapkan terjadi pertambahan kemampuan motorik sesuai dengan tumbuh kembangnya. Akan tetapi pertumbuhan dan perkembangan seseorang pada titik tertentu akan terjadi kemunduran akibat faktor degeneratif (Martini, 2007).

Penelitian Saragih dan Rumapea (2013) menyatakan ada hubungan yang bermakna antara umur dengan tingkat kepatuhan perawat dalam melakukan cuci tangan. Umur berpengaruh terhadap pola fikir seseorang dan pola fikir berpengaruh terhadap perilaku seseorang. Umur seseorang secara garis besar menjadi indikator dalam setiap mengambil keputusan yang mengacu pada setiap pengalamannya, dengan semakin banyak umur maka dalam menerima sebuah instruksi dan dalam melaksanakan suatu prosedur akan semakin bertanggungjawab dan berpengalaman. Semakin cukup umur seseorang akan semakin matang dalam berfikir dan bertindak. 


\section{Karakteristik Responden Berdasarkan Jenis Kelamin}

Tabel 2

Distribusi Frekuensi Responden Berdasarkan Jenis Kelamin di Ruang Rawat Inap RSUD dr. Loekmono Hadi Kudus Juli - Agustus 2017 $\mathrm{n}=153$

\begin{tabular}{ccc}
\hline $\begin{array}{c}\text { Jenis } \\
\text { Kelamin }\end{array}$ & Frekuensi & $\begin{array}{c}\text { Persentase } \\
\text { (\%) }\end{array}$ \\
\hline Laki-laki & 67 & 43,8 \\
\hline Perempuan & 86 & 56,2 \\
\hline Total & $\mathbf{1 5 3}$ & $\mathbf{1 0 0}$ \\
\hline
\end{tabular}

Dari data jenis kelamin pada penelitian ini dapat diketahui bahwa jumlah responden terbesar adalah perempuan. Hasil penelitian ini sesuai dengan penelitian Pakudek (2014) mengenai hubungan motivasi perawat dengan pelaksanaan dokumentasi asuhan keperawatan yang menyatakan bahwa dari 51 responden, yang berjenis kelamin perempuan berjumlah 48 orang.

Analisis peneliti menunjukkan bahwa pekerjaan perawat masih banyak diminati oleh perempuan dibandingkan laki-laki karena keperawatan masih diidentikkan dengan pekerjaan yang cocok dan sesuai dengan sifat perempuan yang lebih sabar, lemah lembut dan peduli (Ilyas, 2011).

\section{Karakteristik Responden Berdasarkan Pendidikan}

Tabel 3

Distribusi Frekuensi Responden Berdasarkan Pendidikan di Ruang Rawat Inap RSUD dr. Loekmono Hadi Kudus Juli - Agustus 2017 $\mathbf{n}=153$

\begin{tabular}{ccc}
\hline Pendidikan & Frekuensi & $\begin{array}{c}\text { Persentase } \\
\text { (\%) }\end{array}$ \\
\hline D3 Kep & 49 & 32,0 \\
S1 Kep & 57 & 37,3 \\
S1 Kep + & 47 & 30,7 \\
Ners & & \\
\hline Total & $\mathbf{1 5 3}$ & $\mathbf{1 0 0}$ \\
\hline
\end{tabular}

Hasil penelitian ini sesuai dengan penelitian Roatib (2007), menyatakan bahwa semakin tinggi pendidikan seseorang semakin tinggi pula pengetahuan dan sikap. Dengan adanya pengetahuan yang memadai seseorang dapat memenuhi kebutuhan dalam mengaktualisasikan diri dan menampilkan produktifitas dan kualitas kerja yang tinggi, serta adanya kesempatan untuk mengembangkan dan mewujudkan kreatifitas.

Hasil penelitian ini sesuai dengan penelitian Putriana (2015) dengan tingkat pendidikan yang ada di ruangan IRNA Utama RSUD Arifin Achmad Pekanbaru yaitu sebagian besar responden berpendidikan S1 Keperawatan memiliki motivasi yang tinggi serta memiliki tingkat kepatuhan dalam pemberian obat oral.

\section{Motivasi Perawat}

Tabel 4

Distribusi Frekuensi Responden Berdasarkan Motivasi Perawat di Ruang Rawat Inap RSUD dr. Loekmono Hadi Kudus Juli - Agustus 2017 $\mathrm{n}=153$

\begin{tabular}{ccc}
\hline $\begin{array}{c}\text { Motivasi } \\
\text { Perawat }\end{array}$ & Frekuensi & $\begin{array}{c}\text { Persentase } \\
\mathbf{( \% )}\end{array}$ \\
\hline Rendah & 5 & 3,3 \\
Sedang & 41 & 26,8 \\
Tinggi & 107 & 69,9 \\
\hline Total & $\mathbf{1 5 3}$ & $\mathbf{1 0 0}$ \\
\hline
\end{tabular}

Hasil penelitian ini sejalan dengan penelitian Mathuridy tahun 2015 yang berjudul hubungan motivasi dengan kepatuhan perawat melakukan enam langkah lima moment cuci tangan di ruang ICU RSUD Ulin Banjarmasin dengan hasil motivasi tinggi 17 (89, 5\%) responden, motivasi sedang $5(45,5 \%)$ responden dan motivasi rendah 0 .

Motivasi diartikan sebagai kekuatan yang terdapat dalam diri individu, yang menyebabkan individu tersebut bertindak atau berbuat, yang tidak dapat diamati secara langsung tetapi dapat diinterpretasikan dalam tingkah lakunya berupa rangsangan dorongan, sehingga menghasilkan tingkah laku tertentu (Mathuridy, 2015). 
Menurut Hamzah (2013) menyimpulkan dari beberapa psikolog menyebutkan motivasi sebagai konstruk hipotesis yang digunakan untuk menjelaskan keinginan, arah, intensitas dan keajegan perilaku yang diarahkan oleh tujuan. Dalam motivasi tercakup konsep-konsep seperti kebutuhan untuk berprestasi, kebutuhan berafiliasi, kebiasaan dan keingintahuan seseorang terhadap sesuatu.

Hasil penelitian lain yang sejalan dengan penelitian ini dilakukan oleh Putriana tahun 2015 dengan judul hubungan motivasi perawat dengan kepatuhan pelaksanaan pemberian obat oral di ruang IRNA Utama RSUD Arifin Achmad Pekanbaru dengan hasil motivasi tinggi $25(53,4 \%)$ responden dan motivasi rendah 21 (45, 7\%) responden.

\section{Kepatuhan Perawat Melaksanakan Five Moment Hand Hygiene}

Tabel 5

Distribusi Frekuensi Responden Berdasarkan Kepatuhan Perawat Dalam Melaksanakan Five Moment Hand Hygiene di Ruang Rawat Inap RSUD dr. Loekmono Hadi Kudus Juli - Agustus 2017 $\mathrm{n}=153$

\begin{tabular}{ccc}
\hline $\begin{array}{c}\text { Kepatuhan } \\
\text { Perawat }\end{array}$ & Frekuensi & $\begin{array}{c}\text { Persentase } \\
\text { (\%) }\end{array}$ \\
\hline Tidak Patuh & 48 & 31,4 \\
Patuh & 105 & 68,6 \\
\hline Total & $\mathbf{1 5 3}$ & $\mathbf{1 0 0}$ \\
\hline
\end{tabular}

Dalam Kamus Besar Bahasa Indonesia, patuh adalah suka menurut perintah, taat pada perintah, sedangkan kepatuhan adalah perilaku sesuai aturan dan berdisiplin. Patuh adalah sikap positif individu yang ditunjukkan dengan adanya perubahan secara berarti sesuai dengan tujuan yang ditetapkan. Kepatuhan adalah suatu perilaku manusia yang taat terhadap aturan, perintah, prosedur dan disiplin.

Hasil penelitian ini sejalan dengan hasil penelitian yang dilakukan di ruang Cendana IRNA I RSUP Dr. Sardjito Yogyakarta menunjukkan kepatuhan cuci tangan dalam kategori patuh sebanyak 39 (97, 5\%) responden dan $1(2,5 \%)$ responden dalam kategori tidak patuh.

Hasil penelitian yang sejalan lainnya dengan penelitian ini dilakukan oleh Putriana tahun 2015 dengan judul hubungan motivasi perawat dengan kepatuhan pelaksanaan pemberian obat oral di IRNA Utama RSUD Arifin Achmad Pekanbaru dengan hasil kategori patuh sebanyak 29 (63, 0\%) responden dan kategori tidak patuh 17 (37, $0 \%$ ) responden.

Menurut Sabarguna (2007) dampak tidak patuh cuci tangan diantaranya akan menimbulkan kesakitan pada individu akibat dari perpindahan mikroorganisme misalnya terjadi sakit perut dan gatal-gatal pada kulit. Bagi tenaga kesehatan, hal kebersihan tangan menjadi salah satu indikator upaya sebuah sistem dalam pencegahan infeksi silang di suatu pelayanan kesehatan. Dampak perawat tidak patuh cuci tangan salah satunya meningkatkan infeksi nosokomial di rumah sakit.

\section{Hubungan Motivasi Perawat Dengan Tingkat Kepatuhan Perawat Dalam Melaksanakan Five Moment Hand Hygiene}

Tabel 6

Hubungan Motivasi Perawat Dengan Tingkat Kepatuhan Perawat Dalam Melaksanakan Five Moment Hand Hygiene di Ruang Rawat Inap RSUD dr. Loekmono Hadi Kudus Juli - Agustus $2017 n=153$

\begin{tabular}{ccc}
\hline Indikator & $\begin{array}{c}\text { Koefisien } \\
\text { korelasi }\end{array}$ & p value \\
\hline $\begin{array}{c}\text { Hubungan motivasi } \\
\text { perawat dengan tingkat } \\
\text { kepatuhan perawat }\end{array}$ & 0,296 & 0,000 \\
\hline
\end{tabular}

Hasil uji Rank Spearman didapatkan hasil p value $=0,000 \leq \alpha=0,05$ maka $\mathrm{Ha}$ diterima dan Ho ditolak yang artinya ada hubungan motivasi dengan tingkat kepatuhan perawat dalam melaksanakan five moment hand hygiene di ruang rawat inap RSUD dr. Loekmono Hadi Kudus. Berdasarkan nilai koefisien korelasi hasil uji 
Rank Spearman diketahui bahwa nilai $r=0$, 296 yang berarti bahwa korelasi antara motivasi dengan tingkat kepatuhan perawat dalam melaksanakan five moment hand hygiene di ruang rawat inap RSUD $\mathrm{dr}$. Loekmono Hadi Kudus menunjukkan tingkat hubungan korelasi sedang, arah korelasi positif yang berarti semakin tinggi motivasi perawat maka semakin tinggi kepatuhan perawat dalam melaksanakan five moment hand hygiene.

Berdasarkan hasil penelitian lain yang sejalan dengan penelitian ini dilakukan oleh Apriliantari tahun 2015 dengan judul hubungan motivasi dengan kepatuhan cuci tangan enam langkah lima momen perawat di IRNA C RSUP Sanglah Denpasarn diperoleh hasil $\mathrm{p}$ value $=0,019$, yang artinya $\mathrm{p}$ value $=0,019<0,05$ maka Ha diterima dan Ho ditolak yang berarti ada hubungan.

Hasil penelitian lainnya yang sejalan dengan penelitian ini dilakukan oleh Mathuridy tahun 2015 dengan judul hubungan motivasi dengan kepatuhan perawat melakukan enam langkah lima moment cuci tangan di ruang ICU RSUD Ulin Banjarmasin diperoleh hasil $\mathrm{p}$ value $=0,014$ dan nilai $\mathrm{r}_{\text {hitung }}=0,445$. Karena hasil $\mathrm{p}$ value $=0,014$ $<$ 0, 05 maka Ha diterima dan Ho ditolak yang berarti ada hubungan dan $\mathrm{r}_{\text {hitung }}=0$, 445 menunjukkan keeratan hubungan sedang.

Hasil penelitian lain yang dilakukan oleh Sumariyem tahun 2015 dengan judul hubungan motivasi dengan kepatuhan perawat dalam praktik hand hygiene di ruang Cendana IRNA I RSUP Dr. Sardjito Yogyakarta diperoleh hasil $\mathrm{p}$ value $<0,05$ yaitu sebesar 0, 000 dengan koefisiensi korelasi sebesar 0, 559 menunjukkan ada hubungan yang bermakna, dengan sifat korelasi memiliki keeratan yang kuat.

Teori motivasi menurut Douglas Mc Gregor bahwa motivasi itu penting untuk mendorong seseeorang dalam bekerja karena motivasi merupakan energi yang mendorong seseorang untuk bangkit menjalankan tugas pekerjaan mencapai tujuan yang telah ditetapkan. Pencapai tujuan dipengaruhi oleh tinggi rendahnya motivasi kerja yang pada akhirnya akan mempengaruhi hasil pekerjaan yang dilakukan (Suyanto, 2009)

Kepatuhan perawat merupakan perilaku perawat yang dapat di observasi dan dapat langsung diukur. Praptianingsih (2007), menyebutkan ada beberapa faktor yang berpengaruh terhadap tingkat kepatuhan antara lain kemampuan, motivasi, masa kerja, latar belakang pendidikan, fasilitas atau peralatan serta kejelasan prosedur.

Motivasi dan kepatuhan itu merupakan hal yang berbanding lurus dalam arti semakin tinggi motivasi yang ada didalam diri perawat maka akan semakin tinggi pula tingkat kepatuhannya dalam melaksanakan five moment hand hygiene.

\section{SIMPULAN}

Motivasi perawat di ruang rawat inap RSUD dr. Loekmono Hadi Kudus dalam melaksanakan five moment hand hygiene sebagian besar dalam kategori motivasi tinggi yaitu sebanyak 107 (69, 9\%) perawat.

Kepatuhan perawat di ruang rawat inap RSUD dr. Loekmono Hadi Kudus dalam melaksanakan five moment hand hygiene sebagian besar dalam kategori patuh yaitu sebanyak $105(68,8 \%)$ perawat.

Terdapat hubungan yang signifikan dan positif antara motivasi perawat dengan tingkat kepatuhan perawat dalam melaksanakan five moment hand hygiene di ruang rawat inap RSUD dr. Loekmono Hadi Kudus dengan nilai $\mathrm{p}$ value $=0,000$ dan rhitung $=0,296$ dengan tingkat hubungan sedang. 


\section{REFERENSI}

Apriliantari, Ni Komang Emi. (2015). Hubungan Motivasi dengan Kepatuhan Cuci Tangan Enam Langkah Lima Momen Perawat di IRNA Sanglah Denpasar. Program Studi Ilmu Keperawatan Universitas Udayana Denpasar. Diakses pada tanggal 10 Desember 2016

Chang, Nai-Chang, dkk. (2013). Feasibility of Monitoring Compliance to the My 5 Moment and Entry/ Exit Hand Hygiene Methods in US Hospital. American Journal of Infection Control. Diakses pada tanggal 14 Desember 2016

Depkes RI. (2011). Profil Kesehatan Indonesia 2010. Jakarta: Departemen Kesehatan Republik Indonesia

Devi dan Wijayanti. (2013). Hubungan Motivasi dengan Kepatuhan Perawat Pelaksana dalam Melaksanakan Perawatan Luka Post Operasi Sesuai dengan SOP di RSUD Batang. Program Studi Ilmu Keperawatan Sekolah Tinggi Ilmu Kesehatan Muhammadiyah Pekalongan Pekajangan. Diakses pada tanggal 5 Januari 2017

Dharma, Kelana Kusuma. (2011). Metodologi Penelitian Keperawatan Panduan Melaksanakan dan Menerapkan Hasil Penelitian. Jakarta : CV Trans Info Media

James, Joyce, dkk. (2008). Prinsip-Prinsip Sains untuk Keperawatan. Jakarta: Erlangga

Lairing, Parida, dkk. (2014). Pengaruh Fungsi Pengarahan Kepala Ruang Terhadap Kepatuhan Perawat Pelaksana Menjalankan Patient Safety: Five Moment Hand Hand Hygiene di Ruang Keperawatan Intensif RSUP DR. Wahidin Sudirohusodo Makassar. Program Studi Magister Keperawatan Universitas Hasanuddin. Diakses pada tanggal 23 Desember 2016

Mathuridy, Marwan Roly. (2015). Hubungan Umur, Lama Kerja, Pendidikan dan Motivasi dengan Kepatuhan Perawat Melakukan Enam Langkah Lima Momen Cuci Tangan di Ruang ICU RSUD Ulin Banjarmasin. Sekolah Tinggi Ilmu Kesehatan Muhammadiyah Banjarmasin. Diakses pada tanggal 5 Januari 2017

Pakudek, Kriska H., dkk. (2014). Hubungan motivasi perawat dengan pelaksanaan dokumentasi asuhan keperawatan di IRNA C RSUP Prof. Dr.
R.D. Kandou Manado. Diakses pada tanggal 5 Agustus 2017

Praptiningsih, S. (2007). Kedudukan Hukum Perawat dalam Upaya Pelayanan Kesehatan di Rumah Sakit. Jakarta: Raja Grafindo

Price, Lesley, dkk. (2013). Toward Improving the World Health Organization Fifth Moment for Hand Hygiene in the Prevention of CrossInfection. American Journal of Infection Control. Diakses pada tanggal 14 Desember 2016

Putriana, Nila., dkk. (2015). Hubungan Motivasi Perawat dengan Kepatuhan Pelaksanaan Pemberian Obat Oral.

Roatib, Ali., Suhatini., Supriyadi. (2007). Hubungan Antara Karakteristik Perawat Dengan Motivasi Perawat Pelaksana Dalam Menerapkan Komunikasi Terapeutik Pada Fase Kerja di Rumah Sakit Islam Sultan Agung Semarang.

Rodyah, Silvi Anita Uslatu. (2015). Hubungan Lingkungan Kerja Perawat dengan Tingkat Kepatuhan Pelaksanaan 5 Momen Hand Hygiene di Ruang Rawat Inap Rumah Sakit Umum Kaliwates PT Rolas Nusantara Medika Jember. Diakses pada tanggal 23 Desember 2016

Sabarguna, B. (2007). Pengendalian Infeksi Nosokomial. Konsursium RSI Jateng

Saragih, Rosita \& Rumapea, Natalina. (2013). Hubungan karakteristik perawat dengan tingkat kepatuhan perawat melakukan cuci tangan di Rumah Sakit Columbia Asia Medan. Diakes pada tanggal 30 Juli 2017

Satrianegara, M. Fais. (2014). Organisasi dan Manajemen Pelayanan Kesehatan Teori dan Aplikasi dalam Pelayanan Puskesmas dan Rumah Sakit. Jakarta: Salemba Medika

Subyantoro, (2009). Penelitian Tindakan Kelas (edisi revisi). Semarang: Undip press

Sukron dan Kariasa, I Made. (2013). Tingkat Kepatuhan Perawat dalam Pelaksanaan Five Moment Hand Hygiene. Fakultas Ilmu Keperawatan Universitas Indonesia. Diakses pada tanggal 5 Januari 2017

Sumariyem, Quirina. (2015). Hubungan Motivasi dengan Kepatuhan Perawat Dalam Praktik Hand Hygiene di Ruang Cendana IRNA I RSUP 
Dr. SARDIITO Yogyakarta. Diakses pada tanggal 2 Agustus 2017

Suyanto. (2009). Kepemimpinan dan Manajemen Keperawatan di Rumah Sakit. Yogyakarta: Mitra Cendekia
World Health Organization. (2010). Guidelines on Hand Hygiene in Health Care. Standard Infection Control Precautions Clinical Governance 